Wippel, John F. 2002. “Thomas Aquinas on the Separated Soul's Natural Knowledge." In Thomas Aquinas: Approaches to Truth, edited by James McEvoy and Michael Dunne (Four Courts), 114-140.

Wolterstorff, Nicholas. 2006. "Suffering Love." In Augustine's Confessions: Critical Essays, edited by William E. Mann (Rowman and Littlefield), 107-146. 


\title{
THEISM AND EXPLANATIONIST DEFENSES OF MORAL REALISM
}

\author{
Andrew Brenner
}

\begin{abstract}
Some moral realists have defended moral realism on the basis of the purported fact that moral facts figure as components in some good explanations of non-moral phenomena. In this paper I explore the relationship between theism and this sort of explanationist defense of moral realism. Theistic explanations often make reference to moral facts, and do so in a manner which is ineliminable in an important respect-remove the moral facts from those explanations, and they suffer as a result. In this respect theistic moral explanations seem to differ from the sorts of moral explanations typically offered by moral explanationists.
\end{abstract}

\section{Introduction}

Let's think of moral realism as the thesis that moral claims aim to report moral facts, some moral claims are true, and the truth values of some such claims are not explained by or dependent upon any human agent's moral beliefs or stipulations. So, for example, the claim "murdering someone for fun is morally wrong" is true, and it is not true because any human believes it to be true, declares or stipulates it to be true, would believe it to be true under epistemically ideal conditions, etc.

Some moral realists have defended moral realism on the basis of the purported fact that moral facts figure as components in some good explanations of non-moral phenomena. ${ }^{1}$ Such philosophers, call them "moral explanationists," argue that some non-moral phenomena are best explained in terms which make reference to moral facts. ${ }^{2}$ So, for example, I believe that Hitler was morally depraved because it is true that Hitler was morally depraved. This sort of explanationism can be given a weaker

\footnotetext{
${ }^{1}$ See, for example, Railton, "Moral Realism"; Boyd, "How to Be a Moral Realist"; Sturgeon, "Moral Explanations" and "Moral Explanations Defended"; and Brink, Moral Realism and the Foundations of Ethics. For a useful overview of this subject see Majors, "Moral Explanation."

${ }^{2} I t$ 's important to focus our attention on whether or not non-moral phenomena are best explained in terms which make reference to moral facts. It is a much less interesting and controversial thesis that some moral facts are best explained in terms of other moral facts, as in, for example, the fact that it is wrong to murder John is explained by the fact that it is wrong to murder anyone.
} 
and a stronger reading. The weaker reading is that the availability of moral explanations of the sort cited by explanationists shows that philosophers who think there can be no such explanations are incorrect. This is important because some philosophers (Gilbert Harman in particular) ${ }^{3}$ argue that moral explanations are problematic in principle, and this shows that there is something wrong with moral realism. The stronger reading of moral explanationist aspirations is that, given the plausibility of some moral explanations of non-moral phenomena, we should accept the moral facts cited in those explanations (for example, that Hitler was morally depraved), thereby accepting moral realism. In other words, according to the stronger explanationist thesis, the plausibility of some moral explanations can be cited as grounds in favor of, or might constitute an argument for, moral realism.

In this paper I explore the relationship between theism and explanationist defenses of moral realism. Where the relationship between theism and moral realism has been discussed, the topic of discussion has almost invariably concerned whether theism provides metaphysical foundations for moral facts. But theism has other implications for how we assess the plausibility of moral realism, as I aim to show here. Theists are in a particularly favorable position to give an explanationist defense of moral realism, insofar as moral facts figure as ineliminable components of good theistic explanations. These moral facts are ineliminable in a manner which isn't true of those moral facts cited in standard extant explanationist defenses of moral realism. ${ }^{4}$

Here's the plan for the remainder of this paper. In §2 I outline Harman's challenge for moral realism, from the purported fact that moral facts fail to explain any non-moral phenomena. In §3 I describe the standard explanationist reply to Harman's challenge, focusing particularly on the work of Nicholas Sturgeon. In §4 I argue that, for those who accept them, theistic explanations provide the resources for an explanationist response

\footnotetext{
${ }^{3}$ See, e.g., Harman, The Nature of Morality, 9.

${ }^{4}$ Here's how this paper relates to previous publications. Robert Adams (Finite and Infinite Goods, 70) briefly makes two of the main points I make in this paper. I discuss his writing on this subject in §4.1. Michael Rea ("Naturalism and Moral Realism") argues that explanationist defenses of moral realism (or, more specifically, naturalistically acceptable explanationist defenses of moral realism) are best developed in terms which require theism or something like theism. While in this respect his thesis is like my own, the argument he gives is very different from the arguments I give in this paper. According to Rea, explanationists should be theists because they will require something like simplicity as a theoretical virtue, but this theoretical virtue will be justifiable only if we endorse theism (or something very much like theism). Dan Baras ("The Explanatory Challenge") argues that if moral realism is not susceptible to a Harman-type explanatory challenge, then neither is theism. In this respect Baras's thesis resembles my own, but Baras's arguments for his thesis are very different from mine. The main respect in which Baras's paper differs from my own is that Baras thinks the prospects for moral explanations of non-moral phenomena are dim. Baras thinks the moral realist, and the theist, should reject or qualify the assumption that they must meet a robust explanatory challenge before moral realism or theism can have epistemic justification. In this paper I remain neutral on that subject. Instead I argue that moral explanations are plausible, given that we accept certain sorts of theistic explanations.
} 
to Harman which avoids the defects of previous such responses. $§ 5$ concludes the paper.

\section{Harman's Challenge}

According to Harman, the problem with morality is "its apparent immunity from observational testing. ${ }^{\prime 5}$ Consider, for example, the following scenario:

You can observe someone do something, but can you ever perceive the rightness or wrongness of what he does? If you round a corner and see a group of young hoodlums pour gasoline on a cat and ignite it, you do not need to conclude that what they are doing is wrong; you do not need to figure anything out; you can see that it is wrong. But is your reaction due to the actual wrongness of what you see or is it simply a reflection of your moral 'sense,' a 'sense' that you have acquired perhaps as a result of your moral upbringing?

Harman argues that our moral judgments in this and similar cases are not "due to the actual wrongness of what we see." In other words, the act's being morally wrong does not explain why we judge it to be wrong. As Loeb $^{7}$ points out, there seem to be two components of Harman's argument that the moral wrongness (or rightness) of any act does not explain why we form the judgment that that act is wrong (or right), namely a simplicity concern and an explanatory impotence concern. It is simpler, Harman claims, to suppose that our moral judgments are merely the results of our background moral beliefs and inclinations, rather than the results of such beliefs and inclinations in addition to the moral facts. As Harman makes the point, "An assumption about moral facts would seem to be totally irrelevant to the explanation of your making the judgment you make. It would seem that all we need assume is that you have certain more or less well articulated moral principles that are reflected in the judgments you make, based on your moral sensibility." 8 The suggestion seems to be that since we need not posit moral facts in order to explain our moral judgments, it would needlessly complicate our total theory if we were to do so. Presumably Harman makes this point because he thinks that we should avoid needlessly complex theories.

Harman's concern regarding the explanatory impotence of moral facts is that there doesn't seem to be any way, either via some sort of causal mechanism or in some other way, in which moral facts can have an impact on which moral judgments we make:

there does not seem to be any way in which the actual rightness or wrongness of a given situation can have any effect on your perceptual apparatus. ${ }^{9}$

${ }^{5}$ Harman, The Nature of Morality, vii.

${ }^{6}$ Harman, The Nature of Morality, 4.

${ }^{7}$ Loeb, “Moral Explanations of Moral Beliefs," 194-195.

${ }^{8}$ Harman, The Nature of Morality, 7.

${ }^{9}$ Harman, The Nature of Morality, 8. 
It appears to be true that there can be no explanatory chain between moral principles and particular observings in the way that there can be such a chain between scientific principles and particular observings. ${ }^{10}$

While so far I've discussed Harman's challenge for the notion that moral facts might explain our moral judgments, I should emphasize that Harman's challenge extends to all moral explanations of non-moral phenomena, not just those involving moral judgments. For example, as we'll see below, Sturgeon claims that the fact that some political or social arrangement is unjust sometimes explains the occurrence of a resulting revolution against that political or social arrangement. Harman would contend, by contrast, that whatever factors bring about the revolution in question, the political or social arrangement's being unjust is not among them. For, first, a sufficient explanation for the revolution can be found in non-moral causes (for example, those non-moral features of the situation on which the situation's being unjust is alleged to supervene). So, to suppose that, in addition to those non-moral features of the situation, the injustice of the situation also helps explain the revolution, we would thereby needlessly complicate to our total picture of the world. A second reason to believe that the situation's being unjust does not explain the revolution is because the injustice of the situation just doesn't seem to be the sort of property the instantiation of which might explain or bring about revolutions. Moral properties like "being unjust" are unable to affect, and therefore unable to explain the occurrence of, the sorts of events which constitute revolutions.

\section{The Explanationist Response to Harman's Challenge}

Since Sturgeon has done more than anyone else to describe and defend moral explanationism, I will restrict my attention to his views on this subject. ${ }^{11}$ Sturgeon thinks Harman is incorrect: not only are moral explanations (that is, explanations of non-moral phenomena which make reference to moral facts) possible, there are in fact many such explanations which seem plausible. So, for example, we think Hitler was morally depraved, and plausibly, part of why we think Hitler was morally depraved is because he was morally depraved. ${ }^{12}$ More generally, there are frequently cases where we consider the best explanation of someone's actions to be that they have such-and-such a moral character. ${ }^{13}$ Such explanations seem plausible and informative. In fact, "it would be difficult to find a serious work of biography, for example, in which actions are not explained by appeal to moral character: sometimes by appeal to specific virtues and vices, but often enough also by appeal to a more general assessment." ${ }^{14}$ To take

\footnotetext{
${ }^{10}$ Harman, The Nature of Morality, 9.

${ }^{11}$ See especially Sturgeon, "Moral Explanations" and "Moral Explanations Defended."

${ }^{12}$ Sturgeon, "Moral Explanations," 234.

${ }^{13}$ Sturgeon, "Moral Explanations," 243-244.

${ }^{14}$ Sturgeon, "Moral Explanations," 244.
} 
another example, between the American Revolution and the Civil War, the American antislavery movement grew tremendously. A good partial explanation for this growth is that "slavery in the United States became a more oppressive institution during that time. The appeal in these standard explanations is straightforwardly to moral facts." ${ }^{15}$ Further examples of plausible moral explanations include political revolutions which have resulted from unjust social or political arrangements. ${ }^{16}$

Support for all such moral explanations comes from the fact that they pass a particular counterfactual test:

it is natural to think that if a particular assumption is completely irrelevant to the explanation of a certain fact, then the fact would have obtained, and we could have explained it just as well, even if the assumption had been false. But I do not believe that Hitler would have done all he did if he had not been morally depraved, nor, on the assumption that he was not depraved, can I think of any plausible alternative explanation for his doing those things. Nor is it plausible that we would all have believed he was morally depraved even if he hadn't been. ${ }^{17}$

Here is another example. Recall the case of the youths setting fire to the cat. In order to assess whether the youths' doing something morally wrong helps explain our belief that they were doing something morally wrong, Sturgeon's counterfactual test asks us to consider whether we would believe the youths were doing something morally wrong if they were not doing something morally wrong. But the youths' doing something morally wrong supervenes on other features of the situation, in particular on the fact that they were causing needless intense suffering. So, a scenario in which the youths were not doing something morally wrong is one in which the facts upon which that moral fact supervenes are altered as well. So, a scenario in which the youths were not doing something morally wrong is one in which they are not causing needless intense suffering. Plausibly enough, if the youth had not been causing needless intense suffering then we would not believe that they were doing anything morally wrong. The moral explanation on offer here-namely, that we believe the youths were doing something morally wrong because they were doing something morally wrong-therefore passes Sturgeon's counterfactual test, and this gives us some reason to think this moral explanation is correct.

So far I've described Sturgeon's explanationist response to Harman's challenge. I'll now offer a new explanationist response: some moral explanations are indispensable components of good theistic explanations. As we'll see, this sort of explanationist defense of moral realism has important advantages over previous explanationist defenses of moral realism.

\footnotetext{
${ }^{15}$ Sturgeon, “Moral Explanations,” 245.

${ }^{16}$ Sturgeon, "Moral Explanations Defended," 244.

${ }^{17}$ Sturgeon, "Moral Explanations," 245-246.
} 


\section{Theistic Explanations}

\subsection{The Theistic Response to Harman's Challenge}

By a "theistic explanation" I mean an explanation of something in terms which make reference to the activities of God, where by "God" I mean an immaterial person who has the omni attributes generally ascribed to God in Western monotheism: God is omnipotent, omniscient, omnibenevolent (i.e., perfectly good), etc. ${ }^{18}$ Theists often explain certain events in terms which make reference to God's desires and intentions: intelligent beings other than God exist because God deliberately created a Universe which was such that it would lead to the evolution of those intelligent beings; such-and-such a miracle occurred because God brought the miracle about; such-and-such a text has the content it has because God inspired or otherwise directed the writers of that text; and so forth. Some theists have gone so far as to say that God's desires and intentions explain everything which happens. I don't need such a strong thesis here. For my purposes I need only assume (if only provisionally, in order to demonstrate their relevance for explanationist defenses of moral realism) that some events are correctly explained in terms of God's deliberate actions, and in particular in terms of God's desire that the events in question come about. Many people endorse theistic explanations of this sort, although the proportion of philosophers who endorse such explanations is small in comparison with the proportion of the general population which endorses such explanations. ${ }^{19}$ (Of course, this same point presumably holds true for moral explanations as well.)

God behaves as God does (at least in part) because God is perfectly good. God will not perform any actions which are morally blameworthy, and God's being perfectly good explains why this is so. Similarly, God will perform many actions which are morally exemplary, and God's being perfectly good explains why this is so. So much is relatively uncontroversial for theists, but anything we say beyond this point is a matter of dispute. A common way of thinking of the matter is this: if there is some state of affairs which God is able to bring about, and which is better than

\footnotetext{
${ }^{18}$ I assume that these divine attributes are unproblematic. If they are problematic, then obviously theism, as I conceive of it, will not aid us in coming up with a response to Harman's explanatory challenge. It will prove to be particularly important that God's omniscience is capable of securing God's moral knowledge. This assumption has been challenged (cf. Baras, "A Reliability Challenge to Theistic Platonism"), but not, I think, successfully. In any case, it would be beyond the scope of this paper to defend this point in any detail. (Although see Brenner, "How Does God Know That $2+2=4$ ?" for a detailed response.)

${ }^{19}$ You can't endorse theistic explanations if you aren't a theist, and since all theists presumably accept some theistic explanations (minimally, the deist thinks that God's creative activities explain why the universe exists), we can regard acceptance of theism as a proxy for acceptance of theistic explanations. Just 14.6 percent of respondents in the 2009 PhilPapers survey accept or "lean toward" theism (Bourget and Chalmers, "What Do Philosophers Believe?" 494). By contrast, adherents of the three major Abrahamic (theistic) religions alone make up roughly 55 percent of the world's population (Pew Research Center, The Global Religious Landscape, 9).
} 
every alternative state of affairs, then inevitably God brings about that state of affairs. Similarly, if there are multiple equally best such states of affairs, then God brings about one of those states of affairs. If there is no best state of affairs, then God at any rate brings about some state of affairs which satisfies certain minimal criteria. ${ }^{20}$ (Here I leave it open what makes some state of affairs better than competing states of affairs. It may be, for example, that part of what makes some state of affairs better than the alternatives is that it satisfies certain deontic moral constraints, while the alternatives do not. I do not mean to suggest, then, that God decides which states of affairs to bring about purely on the basis of consequentialist moral reasoning.) There are going to be important complications which I do not have the space here to discuss in detail, but which will need to be addressed by any fully fleshed out account of how God decides which states of affairs to bring about, or to allow to be brought about by others. For example, Adams ${ }^{21}$ argues that even if there is a best state of affairs, God is not morally obligated to bring it about. Additionally, arguably there are some states of affairs which are possible, but which God is unable to bring about. ${ }^{22}$ God can only be expected to bring about states of affairs which God is able to bring about.

The important point to note is that, while it may prove difficult to spell out in detail exactly which states of affairs God could be expected to bring about, the classical theist should still maintain that God's actions are responsive to the moral facts, in the sense that God performs many of the actions which God performs because God is perfectly good.

So, how does any of this get us an explanationist defense of moral realism? The idea is that moral facts are particularly indispensable in most theistic explanations, in a manner in which they are not indispensable in the sorts of moral explanations which philosophers such as Sturgeon have appealed to. For example, if theism is involved in the best explanation for some event (a purported miracle, or whatever), particular moral claims will probably be involved in the explanation-for example, God brought about such-and-such an event because God is perfectly good (and this is the sort of event a perfectly good being could be expected to bring about), or it satisfied God's desires (where God's desires are, given God's omnibenevolence, responsive to moral facts), etc. So, moral claims act as important components of some good theistic explanations. ${ }^{23}$ This mirrors typical explanationist arguments for moral realism. But with respect to the moral explanations cited by typical moral explanationists the anti-explanationist

${ }^{20} \mathrm{Cf}$. Swinburne, The Existence of God, 112-123.

${ }^{21}$ Adams, "Must God Create the Best?"

${ }^{22}$ Plantinga, The Nature of Necessity, ch. 9.

${ }^{23}$ I don't mean to suggest that all of God's desires, intentions, and preferences are exclusively determined by moral considerations. Perhaps God has some desires, intentions, or preferences for reasons other than the fact that they are morally good, or even for no reason at all (cf. Rea, The Hiddenness of God). Regardless, God's desires, intentions, and preferences 
can say that the moral components of those explanations are problematic, for multiple reasons.

First, as we've seen, Harman would say that moral explanations are objectionably complex. For example, the typical explanationist says Hitler did what he did because Hitler was morally depraved (where the instantiation of moral depravity, suitably spelled out, is a property which Hitler can only have if moral realism is true). Harman's reply, as we've seen above, is that we need not refer to Hitler's depravity, or any other moral property, in order to explain his actions. We can explain Hitler's actions in terms of his having certain beliefs, desires, intentions, etc. Once we have such an explanation of Hitler's behavior, the attribution of moral properties to him becomes unnecessary. We should accept the simpler explanation of Hitler's actions, an explanation in terms which do not attribute moral qualities to Hitler's actions or character traits.

Theistic moral explanations are immune to this sort of simplicity difficulty. In most (perhaps all) theistic explanations, you can't leave out the component of the explanation which says that God is morally exemplary-leaving out that component of the explanation actually makes the explanation less simple. If God's desires, intentions, etc., were not responsive to the moral facts, then God would have a collection of desires, intentions, etc., which are not united by some common feature they all share. It is much simpler to suppose that God has, say, such-and-such desires because God is perfectly good, and those desires are the desires a perfectly good being might be expected to have. In other words, you need only posit God's having this one property (being perfectly good), and God's intentions, desires, etc., come along for free-no need to complicate the theistic hypothesis any further to account for God's having those desires, intentions, etc., which God has. If God is not morally good, because there are no moral facts, then God has various intentions and desires for some reason other than the fact that those intentions and desires are in line with the moral facts. In other words, we would be left with a less theoretically simple sort of theism, where, for example, God has various intentions and desires just as a brute fact. ${ }^{24}$

By contrast, Hitler behaved as he did because he had various desires, intentions, etc., which were the results of a chain of various non-moral historical and psychological causes. Once we've got those miscellaneous non-moral causes as explanations of Hitler's actions, it really does seem gratuitous to attribute moral properties to Hitler's desires, intentions, etc.,

must be consistent with God's moral attributes. What's more, as I've emphasized in the main body of the paper, theistic explanations often contain explicit appeals to God's moral attributes.

${ }^{24}$ Of course, we might wonder why God is perfectly morally good. Is this just a brute fact, or is it to be explained in terms of God's having some other property? Either option is open to the theist. Regarding the latter option, that God is perfectly good as a result of God's having some other property, Swinburne argues that God's perfect goodness (as well as some of the other properties theists have traditionally wanted to attribute to God) follows from God's being omniscient and perfectly free (Swinburne, The Existence of God, 105). 
absent some independent reason to believe there are such moral properties. In other words, there are non-moral historical explanations for why Hitler has the non-moral psychological traits which explain his actions, historical explanations which render any single unifying explanation for why Hitler has the non-moral traits in question superfluous. By contrast, there are no such historical explanations for why God has the non-moral psychological traits which explain God's actions (e.g., God's desires, intentions, etc.). But we can offer a unifying moral explanation for God's having the psychological traits in question, in terms of God's being perfectly good. This is the sense, then, in which I claim that theistic explanations are such that removing the moral components from such explanations makes them less simple. God's moral goodness provides a relatively simple unifying explanation for God's having the intentions and desires that God has. Attributing moral depravity to Hitler, by contrast, has no such unifying effect.

It may help to give an example. Suppose that one of the reasons Hitler behaved as he did was because he was lacking in empathy. We can presumably give a historical explanation for Hitler's lacking empathy, in terms of events in Hitler's life, choices he made at particular points in his life, or whatever. In this case we have non-moral historical explanations for Hitler's instantiating the non-moral property in question (lacking empathy), and, since the instantiation of this and similar non-moral properties is sufficient to explain Hitler's behaviour, we prima facie lack any motivation to ascribe an additional moral property to Hitler, being morally depraved. We need not posit that moral property to unify Hitler's instantiating the non-moral psychological traits in questions, since we already have sufficient non-moral historical explanations for Hitler's instantiating those traits.

By contrast, in God's case we have no historical explanations for God's instantiating many of the non-moral psychological properties which might conceivably explain God's actions. For example, suppose that one successful theistic explanation cites God's creative activities as the explanation for why embodied beings like us exist. Suppose that it is good that embodied beings like us exist. We have two competing explanations for why God created embodied beings like us, partial descriptions of which go like this:

1. God is perfectly good. So, God desires to create things which are good. It would be good if embodied beings like us exist. So, God desired to create embodied beings like us. So, God did create embodied beings like us.

2. God desired to create embodied beings like us. So, God did create embodied beings like us.

The first explanation appeals to moral facts, most importantly the fact that God is perfectly good, and the fact that it would be good if embodied 
beings like us exist. The second explanation appeals only to a non-moral fact, namely that God desired to create embodied beings like us. In the first case we can suppose that God desires to create things which are good because God is perfectly good, and perfectly good beings desire to create things which are good (modulo the complications noted above). But absent moral facts we can give no explanation for why God would desire to create embodied beings like us. That God desires to create embodied beings like us will presumably have to be regarded as a brute fact. Notably, there seem to be no available historical explanations for why God would desire to create embodied beings like us, in contrast with Hitler's having various non-moral attributes, for which there are presumably non-moral historical explanations. But we can make similar points regarding explanations for God's bringing about many other states of affairs. Suppose, for example, that God created a beautiful universe. If God is perfectly good, and if it is good for a beautiful universe to exist, we can give a moral explanation for why God created a beautiful universe. By contrast, if there are no moral facts, then while God may have created a beautiful universe because God desired to create a beautiful universe, there will be no explanation for why God desired to create a beautiful universe. So, absent moral facts, in order to explain why God created embodied beings like us we must appeal to one brute fact regarding God's desires, and in order to explain why God created a beautiful universe we must appeal to some other brute facts regarding God's desires. By contrast, given the availability of moral explanations, we can give a single unified moral explanation for why God created embodied beings like us, and for why God created a beautiful universe, namely an explanation appealing to God's being perfectly good.

We can also see how the theistic moral explanationist can give a response to Harman's concern that moral facts are explanatorily impotent. God is omniscient, so there would be no problem with God's being able to track moral facts. God's (correct) moral beliefs then influence God's actions, and, accordingly, those observable states of affairs we go on to explain in terms of God's activities.

Of course, we can only attribute some observable states of affairs to God's activities if we have reason to believe that those states of affairs are the sorts of states of affairs which God might be expected to bring about. We can only have reason to believe that if our moral beliefs are at least somewhat responsive to the moral facts. But now we're just where Sturgeon was: how do we address Harman's concern that moral facts are explanatorily impotent with respect to our moral beliefs? Theism to the rescue once again. With respect to our moral beliefs, Harman's explanatory impotence concern is no longer a problem, since God can ensure that our evolutionary history (and perhaps cultural practices) would have given us moral belief forming faculties which are largely reliable. ${ }^{25}$ By the

${ }^{25}$ This is a point made by a number of theists: Adams, "Divine Necessity," 751, and Finite and Infinite Goods, 363-366; Swinburne, The Existence of God, 215-218; Rogers, "Evidence for 
same token, Harman's simplicity concern with respect to our moral beliefs is also no longer a problem, since, again, God would have reason to ensure that our moral beliefs are at least somewhat responsive to the moral facts.

It is worth mentioning in passing that these same sorts of considerations provide a response to some widely discussed evolutionary debunking objections to moral realism. ${ }^{26}$ Those debunking objections aim to undermine the epistemological status of our moral beliefs, or moral realism more generally, by appealing to the etiology of those beliefs, an etiology which, it is alleged, we have no reason to believe would have led to truth-conducive beliefs in this area. Theists, I take it, have an obvious response to this concern, one which resembles Descartes' response to a more general skeptical worry, namely that God would ensure that our moral beliefs at least sometimes appropriately track moral facts. This gives us reason to think that the etiology of our moral beliefs, or our moral belief forming faculties more generally, will be to some extent truth-conducive. It is not my goal here to defend this idea. Rather, I'd like to note the consilience afforded to the theist moral realist's treatment of moral epistemology in light of the fact that theism not only seems to provide a ready response to one important epistemological objection to moral realism (that moral facts are explanatorily superfluous, and therefore not worth including in our total theory), but also to another important epistemological objection to moral realism (that our moral beliefs are subject to evolutionary debunking).

Some of the points I've made in this section were anticipated by Adams. ${ }^{27}$ As Adams notes, in a discussion of Harman's explanatory challenge, Leibniz thought that evaluative facts are explanatorily efficacious, insofar as God created the best of all possible worlds because it is the best of all possible worlds. Adams also notes that God might ensure that our moral belief forming faculties are more or less reliable. Here's what Adams says on these subjects:

The implications (for our present topic) of identifying values with theological properties are similar to those of identifying them with natural properties, though the identification will probably have to be supplemented with some theory of divine action in order to yield explanations. If excellence is identified with a sort of Godlikeness, for example, it will contribute to the explanation of the existence of some things if we can correctly suppose that God takes such Godlikeness as a reason for creating things. Even more important, if we suppose that God directly or indirectly causes human beings to regard as excellent approximately those things that are Godlike in the relevant way, it follows that there is a causal and explanatory connection between facts of excellence and beliefs that we may regard as justified about

God From Certainty"; Linville, "The Moral Argument," 393-417; Evans, God and Moral Obligation, 121, 179-181; Thurow, "The Defeater Version of Benacerraf's Problem For A Priori Knowledge," 1601.

${ }^{26}$ As in, e.g., Joyce, The Evolution of Morality, ch. 6, and Street, "A Darwinian Dilemma for Realist Theories of Value."

${ }^{27}$ Adams, Finite and Infinite Goods, 70. 
excellence, and hence that it is in general no accident that such beliefs are correct when they are. ${ }^{28}$

Adams acknowledges that his brief remarks will not satisfy Harman, and his main response to Harman's explanatory challenge does not rely on theistic considerations. ${ }^{29}$

Adams's brief presentation of the theistic response to Harman's explanatory challenge suffers from at least two shortcomings which I've aimed to avoid. First, it is underdeveloped. In particular, it does not tell us why theistic moral explanations do not fall prey to the objections which Harman thinks undermine everyday moral explanations. Second, Adams seems to think that the theistic response to Harman's explanatory challenge works only if we identify value with theological properties (i.e., if we identify excellence with "a sort of Godlikeness"). But this feature of Adams's theistic response to Harman's explanatory challenge seems to me to be unnecessary. God will create excellent things whether or not excellence is identified with "a sort of Godlikeness."

\subsection{So What?}

At this point a significant worry raises its head. We may very well be interested in the various possible responses to Harman's explanatory challenge, and their relative strengths and weaknesses. And perhaps the theistic response to Harman's challenge is of some interest insofar as it has certain advantages over other responses to Harman's challenge. But what should primarily interest us is whether or not Harman's challenge succeeds, and in particular whether we should, in light of Harman's challenge, abandon moral realism. The theistic response to Harman's challenge will only appeal to people who are already theists. Theists, in light of their ascription of moral attributes to God, will already be moral realists. So, what use is the theistic response to Harman in helping us to decide whether or not we should be moral realists?

The theistic moral explanationism discussed in this paper is philosophically significant for several reasons, even if it is not intended to convince anyone that moral realism is true (or, for that matter, that theism is true).

First, it can reassure the theist that they need not be worried about Harman's challenge to moral realism. This is especially important if theism more or less requires moral realism.

Second, it lends some limited support to the thesis that only theists can rationally endorse moral realism. I can't hope to show that there are no non-theistic responses which might also defuse Harman's explanatory challenge, as that would require that I canvas the large literature on the subject, in order to refute every extant non-theistic response to Harman's challenge. That's not something I can hope to accomplish in a single paper. What I have tried to accomplish, however, is to show that the theist has

\footnotetext{
${ }^{28}$ Adams, Finite and Infinite Goods, 70.

${ }^{29}$ See Adams, Finite and Infinite Goods, 70-77.
} 
distinctive resources which help them respond to Harman's challenge, resources which aren't obviously available to non-theists. While a number of philosophers have defended the thesis that one should accept theism if one accepts moral realism, this thesis has not to my knowledge been defended in the manner in which I've defended it here.

Third, until now moral explanationists have only been willing to defend metaethical naturalism (this includes all of the prominent explanationists: Sturgeon, Railton, and Brink, for example)..$^{30}$ Explanationists have always thought that moral facts can figure as components in good explanations of non-moral phenomena only if moral facts are natural facts. Here are some representative quotations:

The idea of causal interaction with moral reality certainly would be intolerably odd if moral facts were held to be sui generis; but there need be nothing odd about causal mechanisms for learning moral facts if these facts are constituted by natural facts, and that is the view under consideration. ${ }^{31}$

\begin{abstract}
Many evaluative explanations of non-evaluative facts look like causal explanations: decency prevents people from doing certain things; injustice, like poverty, can provoke rebellions. And it is hard to see how moral properties like decency and injustice could have these effects unless they were real features of the world. Many philosophers also find it hard to see how they could have such effects in the natural world unless they were themselves natural properties.... So, the acceptability of these explanations, if they are acceptable, would seem to provide an argument against skeptical views that would deny the existence of such properties, and also an argument that the properties in question are natural ones. ${ }^{32}$
\end{abstract}

The theistic moral explanationist can be a metaethical naturalist, but they are also free to be a metaethical non-naturalist. The theist will generally not be moved by prohibitions on the inclusion of non-natural entities or properties in causal explanations. What's more, the particular causal relations at issue will be less problematic for the theistic moral explanationist. How do non-natural moral properties (or events involving such properties) have effects in the natural world? Here's how: they explain God's having particular desires or intentions, and God in turn engages in activities (as a result of God's having the desires or intentions in question) which explain certain natural events. At no point need the causal or explanatory chain be broken simply because the moral properties involved are non-natural: God, being omniscient, has no trouble tracking the non-natural moral facts, and God, being omnipotent, has no trouble intervening in the natural world. (And even if it is problematic to suppose that moral facts cause God to have particular beliefs, desires, intentions,

\footnotetext{
${ }^{30}$ Although it should be noted that they disagree among themselves about how best to characterize metaethical naturalism-e.g., whether we should endorse a reductive or a non-reductive version of naturalism.

${ }^{31}$ Railton, "Moral Realism," 171; see also 185.

${ }^{32}$ Sturgeon, "Moral Explanations Defended," 244.
} 
or whatever, we need not suppose that moral facts causally explain God's having those beliefs, desires, etc. Perhaps, for example, the moral facts ground, rather than cause, God's beliefs, desires, etc. Or perhaps moral facts enter into some other sort of non-causal explanatory relation with God's beliefs, desires, etc. ${ }^{33}$ )

A fourth philosophically significant feature of the theistic moral explanationism discussed in this paper is that it provides a novel perspective on the relationship between theism and moral realism. Usually, when that relationship is discussed, what is discussed is whether God provides any sort of metaphysical foundation for moral facts. ${ }^{34}$ Sometimes the alleged need for such a foundation forms the basis for an argument for the existence of God. ${ }^{35}$ The theistic moral explanationist need not assume that God provides any sort of metaphysical foundation for moral facts. What's more, while theists have sometimes appealed to moral realism as grounds in favor of theism, the theistic moral explanationist turns things around: we should be moral realists because we are theists, or at any rate because we have reason to believe there are good theistic explanations, and that moral facts are indispensable components of those explanations. ${ }^{36}$

A fifth and final point worth mentioning is this. Among other objections to moral explanations, Leiter says that

if we go outside the contemporary philosophical debate and look to scholars in other disciplines actually concerned with explanatory questions, I think we will be hardpressed to find anyone doing serious explanatory work with moral facts. Outside of informal ways of speaking and 'folk explanations,' moral facts appear to play no role in any developed explanatory theory ${ }^{37}$

Theistic moral explanationism reminds us that there is at least one academic discipline, theology, in which moral facts have and continue to play an important explanatory role.

\section{Conclusion}

A major challenge to moral realism has been the objection, most prominently associated with Harman, that moral facts do not explain any non-moral facts. And if moral facts do no such explanatory work, why should we include them in our total picture of the world? Sturgeon and other explanationists have, in response to Harman, provided what they

\footnotetext{
${ }^{33}$ On this subject see Brenner, "How Does God Know That $2+2=4$ ?"

${ }^{34}$ See, for example, Jordan, "Theism, Naturalism, and Meta-Ethics."

${ }^{35}$ As in, for example, Adams, "Moral Arguments for Theism."

${ }^{36}$ Some theists, perhaps sympathetic to this paper's general theiss, might be tempted to argue that the fact that theistic explanations provide the resources for an explanationist defense of moral realism provides some grounds in favor of theism. Zagzebski ("Does Ethics Need God?") and Linville ("The Moral Argument," 393-417) give similar arguments for theism, from the purported fact that theism helps us avoid important epistemological worries for moral realism. I'm not sure what to think about this sort of argument, so I won't try to settle the matter here.
}

${ }^{37}$ Leiter, "Moral Facts and Best Explanations," 94. 
take to be counterexamples to the claim that moral facts do no explanatory work. In this paper I've built on the work of previous explanationists. Here I've argued that theistic explanations (explanations which make reference to God's activities) provide a particularly compelling foundation for the moral explanationist defense of moral realism. Theistic explanations often make reference to moral facts, and do so in a manner which is ineliminable in an important respect-remove the moral facts from those explanations, and they suffer as a result. In this respect theistic moral explanations seem to differ from the sorts of moral explanations typically offered by moral explanationists. I've also argued that the theistic moral explanationist defense of moral realism has at least one other important advantage over previous moral explanationist defenses of moral realism: moral explanationists have always been metaethical naturalists, but the theistic moral explanationist can be either a metaethical naturalist or a non-naturalist. We might also note that my defense of theistic moral explanations shows that, in principle, there can be good moral explanations of non-moral phenomena. One way of interpreting Harman has Harman arguing that, in principle, we cannot have any moral explanations of this sort. Theistic moral explanationism refutes this thesis, whether or not theism is true.

Many of the points I've made in this paper could perhaps be appropriated by proponents of axiarchism, the view that evaluative facts can be directly causally efficacious. ${ }^{38}$ John Leslie, the leading contemporary proponent of this view, thinks that the world exists, and has certain properties, because it is good that the world exist and have those properties. ${ }^{39}$ Axiarchism can be treated as an explanatory theory, so that (perhaps) axiarchism's being true can be cited as the best explanation for why the world exists and has such-and-such properties. But, of course, if axiarchism is true, then realism with respect to some evaluative facts is true as well. It seems, then, that axiarchism is very receptive to an explanationist approach to evaluative realism (if not moral realism specifically). Perhaps similar points could be made about the thesis that some events happen as a result of earned karmic merit. ${ }^{40} \mathrm{On}$ this view, some non-moral facts (e.g., the events which happen to someone) are explained in terms of evaluative facts, namely in terms of the extent to which one has accrued good or bad karmic merit as a result of one's past actions. If karmic laws are justified on explanatory grounds then this might provide another way to develop an explanationist defense of moral realism. Perhaps this sort of explanationist defense of moral realism would have defects which are not present in the theistic explanationist defense of moral realism, aside

\footnotetext{
${ }^{38} \mathrm{~A}$ point also briefly hinted at in Adams, Finite and Infinite Goods, 64-65.

${ }^{39} \mathrm{Cf}$. Leslie, Value and Existence.

${ }^{40}$ Thanks to Brian Barnett for bringing this point to my attention. The thesis that karmic laws operate in the manner described here may be a version of axiarchism, as I've characterized the latter thesis.
} 
from the more general fact that we might think karmic explanations are less plausible than theistic explanations. I'll leave a full discussion of this subject for another occasion. ${ }^{41}$

The University of Gothenburg

\section{References}

Adams, Robert Merrihew. 1972. "Must God Create the Best?" The Philosophical Review 81: 317-332. https://doi.org/10.2307/2184329

Adams, Robert Merrihew. 1983. "Divine necessity." The Journal of Philosophy 80: 741-752. https://doi.org/10.2307/2026018

Adams, Robert Merrihew. 1987. "Moral Arguments for Theism." In The Virtue of Faith and Other Essays in Philosophical Theology (Oxford University Press), 144-163.

Adams, Robert Merrihew. 1999. Finite and Infinite Goods: A Framework for Ethics (Oxford University Press).

Baras, Dan. 2017. "A Reliability Challenge to Theistic Platonism." Analysis 77: 479-487. https://doi.org/10.1093/analys/anx089

Baras, Dan. 2018. "The Explanatory Challenge: Moral Realism is No Better than Theism." European Journal of Philosophy 26: 368-389. https://doi.org/10.1111/ejop.12248

Boyd, Richard. 1988. "How to Be a Moral Realist." In Essays on Moral Realism, edited by Geoffrey Sayre-McCord (Cornell University Press), 181-228.

Bourget, David, and David J. Chalmers. 2014. "What Do Philosophers Believe?" Philosophical Studies 170: 465-500. https://doi.org/10.1007/s11098-013-0259-7

Brenner, Andrew. MS. "How Does God Know That $2+2=4$ ?"

Brink, David. 1989. Moral Realism and the Foundations of Ethics (Cambridge University Press). https://doi.org/10.1017/CBO9780511624612

Evans, C. Stephen. 2013. God and Moral Obligation (Oxford University Press). https://doi.org/10.1093/acprof:oso/9780199696680.001.0001

Harman, Gilbert. 1977. The Nature of Morality: An Introduction to Ethics (Oxford University Press).

Jordan, Matthew C. 2013. "Theism, Naturalism, and Meta-Ethics." Philosophy Compass 8: 373-380. https://doi.org/10.1111/phc3.12021

Joyce, Richard. 2006. The Evolution of Morality (MIT Press).

Leiter, Brian. 2001. "Moral Facts and Best Explanations." Social Philosophy and Policy 18: 79-101. https://doi.org/10.1017/S0265052500002910

Leslie, John. 1979. Value and Existence (Rowman and Littlefield).

\footnotetext{
${ }^{41}$ Thanks to Brian Barnett, Nevin Climenhaga, Dustin Crummett, Brian Cutter, Chad McIntosh, Andrew Moon, several anonymous referees, and the audience at my presentation of this paper at the 2017 American Philosophical Association Pacific Division meeting for very helpful comments on earlier drafts of this paper. Work on this paper was supported by Riksbankens Jubileumsfond.
} 
Linville, Mark D. 2009. "The Moral Argument." In The Blackwell Companion to Natural Theology, edited by William Lane Craig and J. P. Moreland (Wiley-Blackwell), 391-447. https://doi.org/10.1002/9781444308334.ch7

Loeb, Don. 2005. "Moral Explanations of Moral Beliefs." Philosophy and Phenomenological Research 70: 193-208. https://doi.org/10.1111/j.1933-1592.2005.tb00511.x

Majors, Brad. 2007. “Moral Explanation.” Philosophy Compass 2: 1-15. https://doi.org/10.1111/j.1747-9991.2006.00049.x

Pew Research Center. 2012. The Global Religious Landscape: A Report on the Size and Distribution of the World's Major Religious Groups as of 2010.

Plantinga, Alvin. 1974. The Nature of Necessity (Oxford University Press).

Railton, Peter. 1986. “Moral Realism." The Philosophical Review 95: 163-207. https://doi.org/10.2307/2185589

Rea, Michael. 2006. "Naturalism and Moral Realism." In Knowledge and Reality, edited by Matthew Davidson, Thomas Crisp, and David VanderLaan (Kluwer), 215-242. https://doi.org/10.1007/1-4020-4733-9_10

Rea, Michael. 2018. The Hiddenness of God (Oxford University Press). https://doi.org/10.1093/oso/9780198826019.001.0001

Rogers, Katherin A. 2008. "Evidence for God from Certainty." Faith and Philosophy 25: 31-46. https://doi.org/10.5840/faithphil20082512

Street, Sharon. 2006. "A Darwinian Dilemma for Realist Theories of Value." Philosophical Studies 127: 109-166. https://doi.org/10.1007/s11098-005-1726-6

Sturgeon, Nicholas L. 1988. “Moral Explanations.” In Essays on Moral Realism, edited by Geoffrey Sayre-McCord (Cornell University Press), 229-255.

Sturgeon, Nicholas L. 2006. "Moral Explanations Defended." In Contemporary Debates in Moral Theory, edited by James Dreier (Blackwell), 241-262.

Swinburne, Richard. 2004. The Existence of God, 2nd edition (Clarendon Press). https://doi.org/10.1093/acprof:oso/9780199271672.001.0001

Thurow, Joshua C. 2013. "The Defeater Version of Benacerraf's Problem for A Priori Knowledge." Synthese 190: 1587-1603. https://doi.org/10.1007/s11229-011-9894-8

Zagzebski, Linda. 1987. “Does Ethics Need God?” Faith and Philosophy 4: 294-303. https://doi.org/10.5840/faithphil19874331 